\title{
Chiral Enzymatic Activity in Cell Cultures of Taxus Species
}

\author{
Carmen Beatriz Alpízar, ${ }^{1}$ Eduardo Díaz, ${ }^{1}$ Rubén Sánchez-Obregón, ${ }^{1}$ Héctor Barrios, ${ }^{1}$ and Consuelo \\ Sandoval ${ }^{2 *}$ \\ ${ }^{1}$ Instituto de Química, Universidad Nacional Autónoma de México, Circuito Exterior, Ciudad Universitaria, México 04510, \\ D.F., México.barrios@unam.mx \\ 2 Facultad de Química, Universidad Nacional Autónoma de México, Circuito Exterior, Ciudad Universitaria, México 04510, \\ D.F., México
}

Received January 10, 2012; Accepted July 14, 2012

\begin{abstract}
Plant cell suspension cultures of Taxus brevifolia and Taxus globosa were used as biocatalysts on an exogenous racemic substrate in order to determine the influence of several parameters on its configurational deracemization bioactivity. Taxus brevifolia demonstrated a directly proportional relationship between the enantiomeric ratio (er) [1] and the time of reaction, yielding a mixture of $90(S): 10(R)$ after 7 days. Pure enantiomers were tested and the results showed that the $(S)$-enantiomer remained intact, whereas the $(R)$-enantiomer was biotransformed. The buffer solution did not present any effect. Sucrose and temperature modified the reaction time and the er. The $\mathrm{pH}$ was a critical variable in relation to the age of the suspension cultures. Taxus globosa showed a low efficiency for distinguishing between the enantiomers.

Key words: Taxus brevifolia, Taxus globosa, Cell Cultures, Desracemization, Chirality.
\end{abstract}

\section{Introduction}

Plant cell cultures are an important tool in applied studies in several areas. Many plants produce secondary metabolites whose chemical synthesis is not usually feasible economically due to their highly complex structures and specific stereochemistry [2]. Although the use of synthetic techniques for production of medically relevant compounds and for general synthesis has increased substantially, plant cell cultures have provided an alternative and environmentally friendly protocol. Not only has the plant cell culture protocol been used for producing secondary metabolites, it has also served as a biocatalyst for transforming endogenous and exogenous substrates [3-6].

Taxus species have been extensively investigated by several research groups [7-10]. These species produce a family of taxanes including paclitaxel $\left(\mathrm{Taxol}^{\circledR}\right)$, which has been an extremely successful anticancer drug. Research in regard to the biosynthetic pathway of paclitaxel revealed 19 enzymatic steps, which could offer a remarkable enzymatic arsenal for selective biotransformation processes [11].

With the aim of exploring the possibility of advantageously using the amount and types of enzymes available, we recently reported that cell suspension cultures of Taxus globosa Schltdl. and Taxus brevifolia Nutt. were able to cyclize and to reduce chemo- and stereoselectively exogenous substrates under several experimental conditions [12], following our prior
Resumen. Cultivos de células en suspensión de Taxus brevifolia y Taxus globosa se utilizaron como biocatalizadores para determinar, bajo diferentes condiciones, la actividad catalítica de desracemización configuracional ejercida sobre el racemato y enantiómeros puros de un sustrato exógeno. Taxus brevifolia presentó una relación directamente proporcional entre la relación enantiomérica (er) [1] y el tiempo de reacción, dando una mezcla de $90(S): 10(R)$ después de 7 días. La biotransformación de los enantiómeros puros demostró que sólo el isómero $(R)$ fue biotransformado por resolución cinética y, una fracción, mediante estereoinversión en su enantiómero opuesto, mientras que el isómero $(S)$ se mantuvo intacto. Las soluciones reguladoras no presentaron ningún efecto, sin embargo la adición de sacarosa y la temperatura sí modificaron los tiempos de reacción y la er. En relación con la edad de los cultivos y la variación del $\mathrm{pH}$ el efecto fue crítico. Taxus globosa presentó una baja eficiencia en su actividad catalítica configuracional.

Palabras clave: Taxus brevifolia, Taxus globosa, cultivos celulares, desracemización, quiralidad.

research with these species. Here we report their enzymatic deracemization activity on racemic ethyl-3-hydroxybutanoate by transesterification in response to the influence of different reaction parameters: $\mathrm{pH}$, buffer solution, sucrose concentration, temperature, substrate concentration and age of the suspension cultures.

Enantiomers of ethyl-3-hydroxybutanoate and its $\beta$-hydroxyacid are reported as chiral starting materials for the production of numerous biologically active compounds of commercial interest [13-18].

\section{Results and discussion}

Whole cells were used in the context to obtain one pure enantiomer from racemic ethyl-3-hydroxybutanoate as an exogenous substrate. In all cases, analysis of blanks or standards did not show deracemization of the racemic ethyl-3-hydroxybutanoate or racemization of pure enantiomers, which indicates that the results observed in the biotransformations were solely due to enzymatic activity.

\section{Biotransformation with $T$. brevifolia Nutt}

At $\mathrm{pH}$ ranging from 4.0 to 8.0 , the results showed a directly proportional relationship between enantiomeric ratio (er) and 
the reaction time with a straight behavior and with the enantioselectivity maintained during the reaction course. High enantiomeric ratio was obtained at $\mathrm{pH} 4$ after 7 days by adding $10 \% \mathrm{~m} / \mathrm{v}$ of sucrose using citrate-phosphate $(\mathrm{cP})$ as buffer solution (Fig. 1).

Similar activities at $\mathrm{pH} 6.0$ and 7.0 were obtained using $\mathrm{cP}$ or phosphates $(\mathrm{P})$, indicating that the type of buffer solution did not affect the er. The $(S)$-enantiomer was identified as the main constituent in the enantiomeric mixture.

It has been reported that temperature may be a factor in increasing or decreasing the efficiency of enzymatic processes [19]. In order to test this effect, biotransformations were incubated at different temperatures for 7 days (Fig. 2).

The highest activity was observed at $20{ }^{\circ} \mathrm{C}(74 \% \mathrm{er})$. At temperatures $>30{ }^{\circ} \mathrm{C}$, the activity decreased dramatically, resulting in $0-2 \%$ er on day 7 . When the biotransformation was performed at $10{ }^{\circ} \mathrm{C}$, we obtained only $34 \%$ er, with a continuous increase to $65 \%$ er when the reaction time was extended to day 11 (data not shown). At $20^{\circ} \mathrm{C}$ and $30^{\circ} \mathrm{C}$, similar rates of reaction were measured although the reaction course showed instability after 3 days of incubation, resulting in $50 \%$ er by day 7.

Many enzymatic processes, and thus their resultant yields, are known to be limited by the substrate concentration, e.g.,

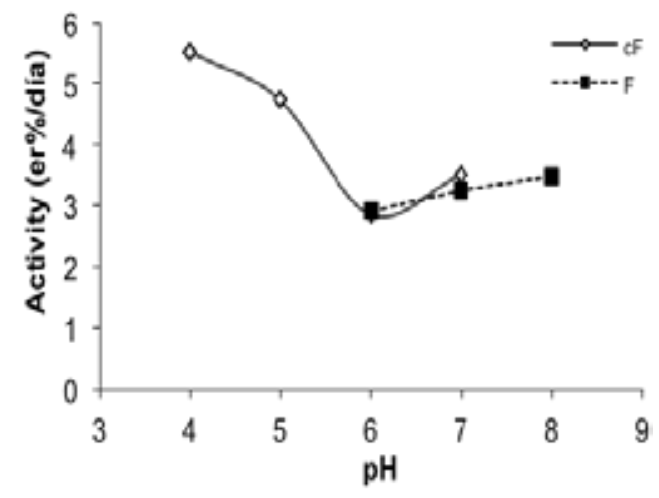

Fig. 1. Effect of $\mathrm{pH}$ on biotransformation of racemic ethyl-3-hydroxybutanoate in T. brevifolia Nutt.

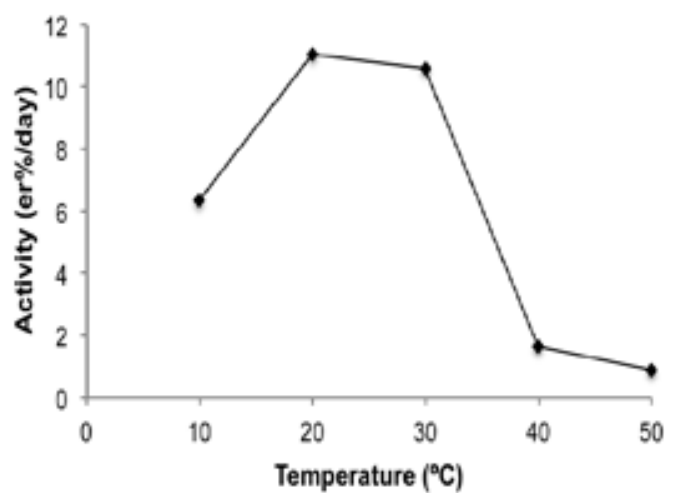

Fig. 2. Influence of temperature on biotransformation in T. brevifolia Nutt. after 7 days. enantioselectivity was affected when cyclohexanone monooxygenase from Acinetobacter calcoaceticus was used to biotransform, through an enantiodivergent oxidation, racemic bicycle[3.2.0]hept-2-en-6-one into lactones [20]. In view of the above statements, different substrate concentrations were tested to determine any modifications in the er and/or enantioselectivity. The results showed that the enantioselectivity did not change, and in all cases the $(S)$-enantiomer was obtained (Fig. 3).

However, the er showed an inversely proportional relationship with the substrate concentration with higher er being obtained at $0.05 \% \mathrm{v} / \mathrm{v}(71 \%$ er by day 5$)$ compared to $0.2 \%$ and $0.6 \% \mathrm{v} / \mathrm{v}$ with $26 \%$ and $4 \%$ er, respectively.

In order to investigate the enantiomer behavior, pure $(R)$ and $(S)$-enantiomers were used independently with whole cells of T. brevifolia Nutt. in $0.1 \% \mathrm{~m} / \mathrm{v}$ and $0.2 \% \mathrm{~m} / \mathrm{v}$ of substrate to eliminate any enzymatic saturation. As shown in figure 4, pure $(S)$-enantiomer was totally recovered in both concentrations, whereas only $10 \%$ of chemical yield was obtained as a mixture in the proportion $10(S): 90(R)$ when pure $(R)$-enantiomer was inoculated ( $R 0.1 \%$ and $R 0.2 \%$ ). At the same time, racemic-ethyl 3-hydroxybutanoate was used under the same

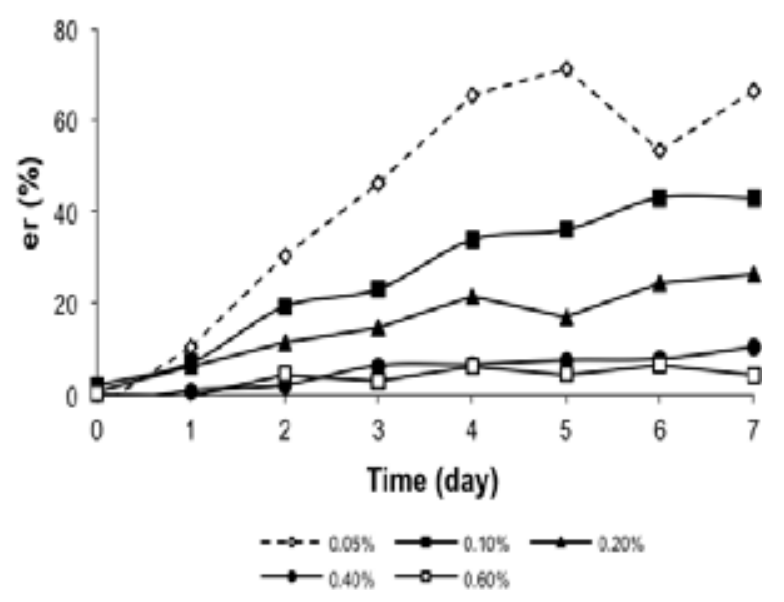

Fig. 3. Enantiomer ratio dependence of racemic substrate concentration in T. brevifolia.

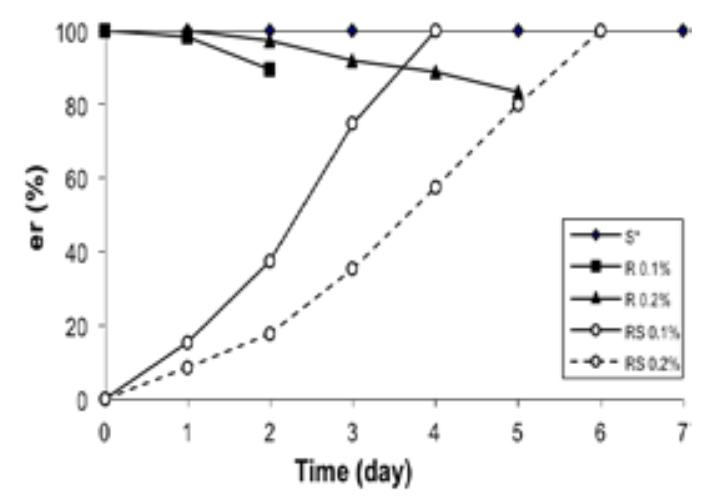

Fig. 4. Reaction course using racemic and enantiomeric ethyl-3hydroxybutanoate in T. brevifolia. $S^{*}: 0.1 \%$ and $0.2 \% \mathrm{v} / \mathrm{v}$. 
conditions and concentrations with the results showing that er was increased with prolonged reaction times resulting in the same mixture proportion of $90(S): 10(R)$. These results revealed that the $(S)$-enantiomer remained intact in the reaction media during the reaction time and that only $10 \%$ of the pure $(R)$-enantiomer was changed into the opposite enantiomer by stereoinversion, according to one of the mechanisms of chiral resolution [21] (Fig. 4).

In the case of racemic ethyl-3-hydroxybutanoate, production of an er was possible because the $(R)$-enantiomer was biotransformed to $(S)$-enantiomer by a kinetic resolution mechanism [22] confirmed when we obtained a chemical yield range of 30 to $56 \%$.

Finally, when different $\mathrm{pH}$ values were tested with $10 \% \mathrm{v} /$ $\mathrm{m}$ of sucrose at $20^{\circ} \mathrm{C}$ and with $0.2 \% \mathrm{v} / \mathrm{v}$ of substrate concentration, higher values of er were found at $\mathrm{pH} 8.0$ and $\mathrm{pH} 4.0$ than at intermediate pHs. In order to better understand these results, and because several assays were performed during different stages of continuous cultivation, we compared the influence of suspension culture age with the influence of other parameters such as $\mathrm{pH}$.

Suspension cultures of Taxus brevifolia Nutt. were maintained for 1 year and 9 months. The results presented in Figure 5 showed that, 3 months after generation of the suspension cultures, greater activity was achieved at $\mathrm{pH} 8.0(73 \% \mathrm{er})$ than at $\mathrm{pH} 4.0(26 \%$ er). However, 5 months later the er was elevated at $\mathrm{pH} 4.0(60 \%$ er), whereas at $\mathrm{pH} 8.0$ it decreased to $22 \%$ er. A consistent level of activity was observed during months 1315 at $\mathrm{pH} 4.0(80 \%$ er), whereas activity was decreased during suspension culture maintenance at $\mathrm{pH} 8.0$ (Fig. 5).

Production of secondary metabolites in several plant cell cultures decreased with culture age [2]. In Taxus species, paclitaxel production is not constant but rather is influenced by season in vivo [23-25]. Additionally, paclitaxel production is also influenced by the age of the suspension in vitro [9]. Difficulties encountered when establishing cell cultures such as cessation of cell growth/production of the secondary metabolites after a period of time in suspension can be attributed to the changes in genomic structures [26]. Metabolic changes associated with genomic instability may affect cellular metabolic activity and

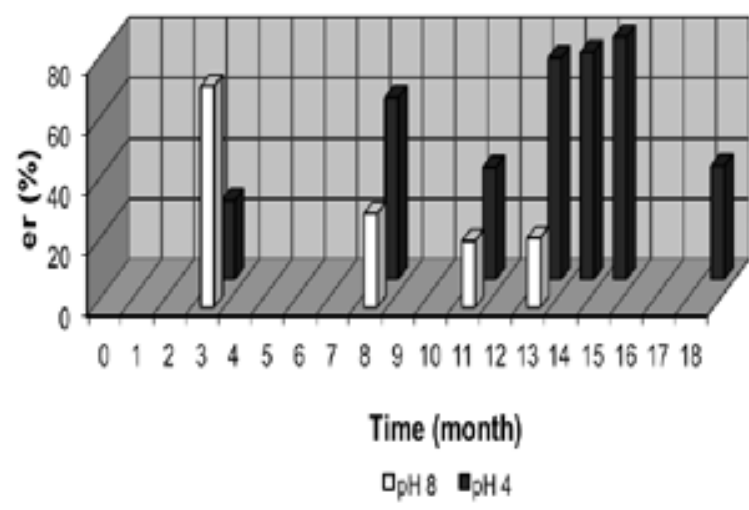

Fig. 5. Influence of age of the suspension cultures on the optimum $\mathrm{pH}$ in the biotransformation of racemic ethyl-3-hydroxybutanoate using T. brevifolia. thus may modify the $\mathrm{pH}$ conditions in which kinetic resolution results in one pure enantiomer. The GC chromatograms showed a similar pattern at both $\mathrm{pH}$ values across culture ages, and new signals were not observed. This is the first report showing that reaction conditions must be modified according to the age of the suspension culture in order to biotransform an exogenous substrate such as ethyl-3-hydroxybutanoate.

\section{Biotransformation with Taxus globosa Schltdl}

Previous studies mentioned that most enzymatic processes operate under neutral aqueous conditions [27, 28]; therefore, we performed the biotransformation under standard conditions $(\mathrm{pH}$ 6.5 and 7.0) to obtain one pure enantiomer. As a result, we obtained the $(S)$-enantiomer with values of $1 \%$ and $3 \%$ of er on day 7. When several $\mathrm{pH}$ values (4.0-8.0) were tested with daily sample collection, we observed a $16 \%$ er for the $(S)$-enantiomer and chemical yields ranging from $89 \%$ to $92 \%$ within the same time frame.

The presence of sucrose favored er with an approximate $50 \%$ increase being observed. The reaction courses for all $\mathrm{pH}$ treatments are presented in Table 2.

The results showed an oscillatory behavior between er and reaction time, resulting in enantioselectivity changes according to $\mathrm{pH}$ conditions within 1 week. In the course of 1 day, we observed an increase of er in all $\mathrm{pH}$ treatments, but by the second day the opposite was observed with the exception of the treatment at $\mathrm{pH} 6.5$ and 8.0. By the third day, a decrease in er was observed at $\mathrm{pH} 6.5$, whereas a continuous increase was observed at $\mathrm{pH}$ 8.0. These results exhibited no periodic dependence between er and reaction time. Both enantiomers were identified as the main product in the enantiomeric mixture. At $\mathrm{pH}$ values of 4.0 and 6.0 , the oscillatory behavior was also present, but the opposite enantioselectivity was observed during the reaction course because the $(R)$-enantiomer was mainly obtained. Enantioselective changes were previously reported when racemic benzoin was deracemized by Rhizopus oryzae at $\mathrm{pH}$ 7.5-8.0 and $\mathrm{pH} 4.0-5.0$ [29].

The present results suggest that Taxus globosa Schltdl. cells are capable of transforming one enantiomer, depending on the $\mathrm{pH}$. When racemic ethyl-3-hydroxybutanoate was used, the cells could produce $(S)$ - or $(R)$-enantiomers, causing an oscillatory behavior related to $\mathrm{pH}$ changes in the reaction media or within the cells. The result is an inefficient process for obtaining a pure enantiomer. Racemic ethyl-3-hydroxybutanoate was inoculated in the reaction media without cells as a control experiment and was recovered with no change.

\section{Experimental procedures}

\section{Plant material}

Callus tissues of Taxus brevifolia Nutt. were induced from young stems. These were subcultured for 2 years using the experimental conditions previously reported [12], whereas callus 
Table 1. Enantiomeric ratio on the biotransformation with whole cells of $T$. globosa Schltdl. after 7 days

\begin{tabular}{lrr}
\hline $\mathrm{pH}$ & {$[\mathrm{er}(\%)]$} \\
\hline 4 & $3.5(R)$ \\
5 & 6 & $(S)$ \\
6 & 0 & \\
6.5 & 1 & $(S)$ \\
7 & 3 & $(S)$ \\
8 & 16 & $(S)$ \\
8 & 7 & $(S)$ \\
\hline
\end{tabular}

${ }^{\text {a}}$ Without sucrose.

er, enantiomeric ratio.

Table 2. Enantiomeric ratio (er) dependence (\%) on the reaction time at several values of $\mathrm{pH}$ using T. globosa Schltdl.

\begin{tabular}{ccccccc}
\hline \multicolumn{6}{c}{ er (\%) in several values of $\mathrm{pH}$ (main enantiomer) } \\
\hline $\begin{array}{c}\text { Reaction time } \\
\text { (days) }\end{array}$ & $4(R)$ & $5(S)$ & $6(R)$ & 6.5 & $7(S)$ & $8(S)$ \\
\hline 0 & 0 & 0 & 0 & 0 & 0 & 0 \\
1 & 0.5 & 2 & 2 & 1 & 1.5 & 1 \\
2 & 2 & 0 & 0 & 4 & 0 & 2 \\
3 & 2 & 1 & nd & 1 & 5 & 5 \\
4 & 3 & 2.5 & 6 & 6 & 2 & 7 \\
5 & 2.5 & 1.5 & nd & 5 & 2 & 8 \\
6 & 4 & 3 & nd & 2 & 1.5 & 13 \\
7 & 3.5 & 6 & 0 & 1 & 3 & 16 \\
\hline
\end{tabular}

nd, not determined.

tissues of Taxus globosa Schltdl. were induced from mature shoots and maintained by subculturing for 1 year. T. brevifolia Nutt. callus was transferred to Erlenmeyer flasks $(250 \mathrm{~mL})$ containing B5NB liquid medium supplemented with $2 \% \mathrm{~m} / \mathrm{v}$ of sucrose and $1 \% \mathrm{~m} / \mathrm{v}$ of PVP, regulating at $\mathrm{pH} 5.5$ after sterilization. Taxus globosa Schltdl. callus were transferred to Erlenmeyer flasks $(250 \mathrm{~mL})$ with $\mathrm{SH}$ liquid medium containing 1 $\mathrm{mg} / \mathrm{L}$ of NAA, $0.5 \mathrm{mg} / \mathrm{L}$ of $2,4-\mathrm{D}, 0.05 \mathrm{mg} / \mathrm{L}$ of BA, $1.5 \% \mathrm{~m} / \mathrm{v}$ sucrose and $1 \% \mathrm{~m} / \mathrm{v}$ PVP at $\mathrm{pH}$ 5.6, adjusted after sterilization. Both plant cell cultures were maintained under dark conditions on a rotary shaker $(100 \mathrm{rpm})$ at $20{ }^{\circ} \mathrm{C}$, replacing old media with fresh media every 15 days for 5 weeks. From week 6 , biotransformations were performed and subsequent experiments were carried out with suspensions of cells in continuous culture.

\section{Biotransformation with Taxus brevifolia Nutt}

After filtration, $14 \mathrm{~g}$ fresh weight of cells were resuspended in Erlenmeyer flask (250 mL) containing $40 \mathrm{~mL}$ of buffer solution under dark conditions on a rotary shaker (100 rpm) at $20{ }^{\circ} \mathrm{C}$ (except for the experiment) to determine temperature dependence. Racemic ethyl-3-hydroxybutanoate $(0.2 \% \mathrm{v} / \mathrm{v})$ and sucrose $(10 \% \mathrm{~m} / \mathrm{v})$ were added to the biotransformation reaction mixture.

The influence of $\mathrm{pH}$ was determined by measuring the er at several $\mathrm{pH}$ values. Buffer solutions used were citrate $(50$ $\mu \mathrm{M})$-phosphate $(100 \mu \mathrm{M})(\mathrm{pH} 4.0-7.0)$ and phosphates $(200$ $\mu \mathrm{M})(\mathrm{pH}$ 6.0-8.0). The influence of sucrose concentration was tested in its absence at $\mathrm{pH}$ 8.0. To determine the influence of temperature, 7-day incubation was performed at temperatures ranging from $10^{\circ} \mathrm{C}$ to $50{ }^{\circ} \mathrm{C}(\mathrm{pH} 4.0)$ with $10 \%$ sucrose.

Different concentrations (v/v) of racemic ethyl-3-hydroxybutanoate were tested to determine the influence of concentration on activity (Fig. 3). Biotransformation was performed by adding $10 \% \mathrm{~m} / \mathrm{v}$ sucrose at $\mathrm{pH} 4.0$. Analysis of each pure enantiomer during its biotransformation was independently carried out with $0.1 \%$ and $0.2 \% \mathrm{v} / \mathrm{v}$ of $(R)$-ethyl-3-hydroxybutanoate and $(S)$-ethyl-3-hydroxybutanoate. Racemic ethyl-3-hydroxybutanoate was used as a control experiment at the same concentrations. Appropriate control experiments with each type of biotransformation were tested by mixing all the components except i) racemic ethyl-3-hydroxybutanoate or each pure enantiomer and ii) whole cells. The final enantiomeric excess and chemical yield were determined.

\section{Biotransformation with Taxus globosa Schltdl}

The cells were harvested by filtration and $14 \mathrm{~g}$ fresh cell weight were suspended in a $250 \mathrm{~mL}$ Erlenmeyer flask containing 40 $\mathrm{mL}$ of buffer solution with the addition of $10 \% \mathrm{~m} / \mathrm{v}$ sucrose and $0.2 \% \mathrm{v} / \mathrm{v}$ racemic ethyl-3-hydroxybutanoate. The biotransformation reaction was incubated under dark conditions on a rotary shaker $(100 \mathrm{rpm})$ at $20^{\circ} \mathrm{C}$ for 7 days while monitoring the er. Several values of $\mathrm{pH}$ were tested. Buffer solutions used were as follows: citrate $50 \mu \mathrm{M}$-phosphate $100 \mu \mathrm{M}(\mathrm{pH} 4.0$ 7.0) and phosphates $200 \mu \mathrm{M}$ ( $\mathrm{pH} 6.0-8.0$ ). To determine the influence of sucrose, biotransformation was performed in its absence at $\mathrm{pH} 8.0$.

Control experiments were performed with i) whole cells and ii) racemic ethyl-3-hydroxybutanoate in each buffer solution with or without $10 \% \mathrm{~m} / \mathrm{v}$ of sucrose.

\section{General methods}

${ }^{1} \mathrm{H}$ NMR spectra were recorded with a Varian Unity Detector at $300 \mathrm{MHz}$ using $\mathrm{CDCl}_{3}$ as the solvent and $\mathrm{Me}_{4} \mathrm{Si}$ (TMS) as the internal reference. Biotransformations were monitored by GC in an Agilent 6890 chromatograph using hydrogen as a carrier gas. The yield was determined with an Alltech ATTMAquaWax column $(30 \mathrm{~m} \times 0.25 \mathrm{~mm}$ ID $\times 0.25 \mu \mathrm{m})$ with the following conditions: constant flow rate of $2 \mathrm{~mL} / \mathrm{min}$, oven temperature of $130^{\circ} \mathrm{C}$, injector and FID detector temperature of $230{ }^{\circ} \mathrm{C}$ and split of 200 . Retention times were $32.2 \mathrm{~min}$ for $(S)$-ethyl-3-hydroxybutanoate and $33.3 \mathrm{~min}$ for $(R)$-ethyl3-hydroxybutanoate. The er was determined with a Restek RT- $\gamma$ DEXsa column $(30 \mathrm{~m} \times 0.32 \mathrm{~mm}$ ID $\times 0.25 \mu \mathrm{m})$ using a constant flow rate of $2 \mathrm{~mL} / \mathrm{min}$, oven temperature of 90 ${ }^{\circ} \mathrm{C}$, injector and FID detector temperature of $200{ }^{\circ} \mathrm{C}$ and split 
of 20. Under these conditions, retention times were $3.2 \mathrm{~min}$ for $n$-hexanol and $5.3 \mathrm{~min}$ for racemic ethyl 3-hydroxybutanoate.

\section{Racemic ethyl-3-hydroxybutanoate}

The exogenous substrate was obtained by reduction of ethyl acetoacetate $(25 \mathrm{~g}, 0.19 \mathrm{~mol})$ with sodium borohydride (1.85 $\mathrm{g}, 0.04 \mathrm{~mol})$ in ethanol $(500 \mathrm{~mL})$ under magnetic stirring for 4 h. A saturated solution of $\mathrm{NaCl}(30 \mathrm{~mL})$ was added, extracted with ethyl ether $(3 \times 90 \mathrm{~mL})$, and the organic phase dried over $\mathrm{Na}_{2} \mathrm{SO}_{4}$ was concentrated. The residue was distilled $\left(74^{\circ} \mathrm{C}, 20\right.$ $\mathrm{mmHg}$ ) obtaining a colorless liquid. ${ }^{1} \mathrm{H}$ NMR spectrum was in agreement with the literature and the purity was determined by GC/FID using an Alltech ATTM-AquaWax column.

\section{Determination of enantiomeric ratio and yield}

The progress of er development was monitored every $24 \mathrm{~h}$ by collecting $1 \mathrm{~mL}$ samples. These samples were centrifuged $(11,500 \mathrm{rpm}, 5 \mathrm{~min})$ and the supernatant was extracted with ethyl ether $(2 \times 400 \mu \mathrm{L})$. The organic phase was analyzed by chiral GC/FID. The yield was determined by collecting $1 \mathrm{~mL}$ samples at the end of the biotransformation (7 days). These samples were centrifuged (11,500 rpm, $5 \mathrm{~min})$ and the supernatant was analyzed by GC/FID using $n$-hexanol as the internal standard.

\section{Acknowledgements}

We gratefully acknowledge M. Sc. Carmen Márquez for help with the GC analysis. Consejo Nacional de Ciencia y Tecnología provided a fellowship to Carmen B. Alpízar.

\section{References}

1. Gawley, R. E. J. Org. Chem. 2005, 71, 2411-2416.

2. Namdeo, A. G. Phcog. Rev. 2007, 1, 69-79.

3. De Carvalho, C. C. C. R.; Da Fonseca, M. M. R. Biotechnol. Adv. 2006, 24, 134-142.

4. Furuya, T. Yakugaku zasshi. 1988, 108(8), 675-696.

5. Ishihara, K.; Hamada, H.; Hirata, T.; Nakajima, N. J. Mol. Catal. B: Enzym. 2003, 23, 145-170.
6. Shimoda, K., Kubota, N., Hamada, H.; Hamada, H. Tetrahedron Lett. 2006, 47, 1541-1544.

7. Ketchum, R. E. B.; Gibson, D. M. Plant Cell Tissue Organ Cult. 1996, 46, 9-16.

8. Kim, J. H.; Yun, J. H.; Hwang, Y. S.; Byun, S. Y.; Kim, D. I. Biotechnol. Lett. 1995, 17, 101-106.

9. Kim, B. J.; Gibson, D. M.; Shuler, M. L. Biotechnol. Prog. 2004, 20, 1666-1673.

10. Kingston, D. G. I. and Newman, D. J. Curr. Opin. Drug Disc. Devel. 2007, 10, 130-144.

11. Croteau, R.; Ketchum, R. E. B.; Long, R. M.; Kaspera, R.; Wildung, M. R. Phytochem. Rev. 2006, 5, 75-97.

12. Sandoval, C.; Méndez, J. M.; Sánchez-Obregón, R.; Alpízar, C. B.; Barrios, H. Biocatal. Biotransform. 2009, 27(1), 36-44.

13. Blacker, A. J.; Holt, R. A., in: Chirality in industry II, Collins, A. N.; Sheldrake, G. N.; Crosby, J., Eds., Wiley, UK, 1997, 245262.

14. Bucciarelli, M.; Davoli, P.; Forni, A.; Moretti, I.; Prati, F. J. Chem. Soc., Perkin Trans. 1. 1999, 2489-2494.

15. Chiba, T.; Nagatsuma, M.; Nakai, T. Chem. Lett. 1985, 5, 651654.

16. Mori, K. Tetrahedron, 1989, 45, 3233-3298.

17. Seebach, D.; Chow, H.; Jackson, R.F.W.; Sutter, M.A.; Thaisrivongs, S.; Zimmermann, J. Liebigs Ann. Chem. 1986, 7, 12811308.

18. Seebach, D.; Roggo, S.; Zimmermann, J., in: Stereochemistry of organic and bioorganic transformation. Bartmann, W.; Sharpless, K. B., Eds., VCH, Germany, 1987, 85-126.

19. Burton, S. G.; Cowan, D. A.; Woodley, J. M. Nat. Biotechnol. 2002, 20, 37-45.

20. Zambianchi, F.; Pasta, P.; Ottolina, G.; Carrea, G.; Colonna, S.; Gaggero, N.; Ward, J.M. Tetrahedron: Asymmetry. 2000, 11, 3653-3657.

21. Gruber, C. C.; Lavandera, I.; Faber, K.; Kroutil, W. Adv. Synth. Catal. 2006, 348, 1789-1805.

22. Strauss, U. T.; Felfer, U.; Faber, K. Tetrahedron: Asymmetry. 1999, 10, 107-117.

23. Ramos-Lobato, N. A.; Soto-Hernández, M.; Zavala-Chávez, F.; Rodríguez-González, M. T. Revista Chapingo Serie Horticultura, 2003, 9, 29-38.

24. Soto Hernández, M.; Sanjurjo, M.; González Garza, M.T.; Cruz Vega, D.; Giral González, F. Ciencia Ergo Sum. 2001, 7, 277278.

25. Ketchum, R. E. B.; Gibson, D. M. Plant Cell Tissue Organ Cult. 1996, 46, 9-16.

26. Baebler, Š.; Hren, M.; Camloh, M.; Ravnikar, M.; Bohanec, B.; Plaper, I.; Ucman, R.; Žel, J. In vitro Cell. Dev. Biol. - Plant. 2005, 41, 338-343.

27. Koeller, K. M.; Wong, C. Nature, 2001, 409, 232-240.

28. Thomas, S. M.; DiCosimo, R.; Nagarajan, V. Trends Biotechnol. 2002, 20, 238-242.

29. Demir, A. S.; Mamamci, H.; Sesenoglu, O.; Neslihanoglu, R.; Asikoglu, B.; Capanoglu, D. Tetrahedron Lett. 2002, 43, 64476449. 